DOI: $\underline{10.35619 / \text { iiu.v1i10.179 }}$

Павлюк Тетяна

кандидат педагогічних наук, доцент, доцент кафедри педагогіки та психології (дошкільної та корекційної) імені проф. Т. І. Поніманської Рівненського державного гуманітарного університету, м. Рівне, Україна

ORCID: 0000-0001-7237-0869

e-mail: nadahovskat@ukr.net

\title{
ПІДГОТОВКА МАЙБУТНІХ ВИХОВАТЕЛІВ ДО ЗАСТОСУВАННЯ НАРОДНОЇ МАТЕМАТИКИ В ПРАКТИЦІ НАВЧАННЯ ДІТЕЙ ДОШКІЛЬНОГО ВІКУ В УМОВАХ ІНКЛЮЗИВНОЇ ГРУПИ
}

\begin{abstract}
Анотація. У статті здійснено аналіз стану підготовки майбутніх вихователів до використання в сучасних закладах дошкільної освіти елементів народної математики. Висвітлено погляди вчених на означену проблему 3 урахуванням вимог часу навчання дітей $з$ особливими потребами разом із здоровими однолітками в умовах інклюзивної групи. Розглянуто чинники, які впливають на недостатньо інтенсивне впровадження інклюзивної освіти в Україні і створення простору, дружнього до дітей $з$ особливими потребами, зокрема - 3 порушеннями опорно-рухового апарату. Увагу акцентовано на підвищенні ефективності підготовки здобувачів вищої освіти завдяки відродженню методичних прийомів виховання підростаючого покоління засобами народної математики. Матеріал 3 народної математики органічно поєднується 3 сучасними методиками формування елементарних математичних уявлень у дітей дошкільного віку, доповнює та раціоналізує освітній процес, а також сприяє підвищенню пізнавального інтересу до навчання.

Ключові слова: дитина дошкільного віку, дитина 3 особливими освітніми потребами, інклюзія, інклюзивна група, народна математика, заклад дошкільної освіти, майбутній вихователь.
\end{abstract}

Постановка проблеми. Модернізація та оновлення змісту підготовки майбутніх вихователів здійснюється в умовах реформування освітньої галузі. Сучасний педагог має поєднувати в собі низку професійних компетентностей, володіти традиційними методиками дошкільної педагогіки, інноваційними технологіями та знаннями, вміннями і навичками роботи в інклюзивній групі. Все це слід поєднувати i компонувати із українськими традиціями народної педагогіки. Це стимулює до творчого пошуку дієвих засобів національного виховання і навчання підростаючого покоління, що матиме на меті збереження традицій народної педагогіки, позаяк гостро актуальною $є$ проблема залучення нових поколінь до національної культури. Саме народна математика здатна дієво підвищити пізнавальний інтерес дітей дошкільного віку з різними освітніми потребами в умовах інклюзивної групи.

Аналіз останніх досліджень і публікацій. Учені Н. Бібік, В. Бондар, С. Бондар, Л. Ващенко, І. Гавриш, Н. Коломієць, І. Хижняк, О. Чиж, І. Шапошнікова, К. Юр'єва та ін. акцентують увагу на широкому спектрі навчально-розвивальних, виховних завдань, які необхідно буде розв'язувати майбутньому педагогу. Концептуальні засади професійної підготовки майбутніх фахівців дошкільної освіти розкриваються в дослідженнях А. Богуш, І. Дичківської, О. Кононко, Т. Поніманської, О. Савченко та iH. 
Інклюзивна освіта цікавить широке коло вчених - І. Білозерська, А. Колупаєва, Ю. Найда, Л. Савчук, Н. Софій, О. Таранченко, П. Придатченко, З. Шевців.

У дослідженнях, присвячених проблемі математичного розвитку дошкільників, увага акцентується на формуванні в дітей математичних знань про кількісні відношення, форму, величину предметів, орієнтування в просторі і часі - Р. Березіна, Л. Гайдаржийська, В. Колечко, З. Лебедєва, Г. Леушина, К. Назаренко, А. Столяр, К. Щербакова та ін.; формування логіко-математичної компетенції - Л. Зайцева, Т. Степанова. Народна математика є предметом дослідження Н. Баглаєвої, В. Бобиніна, Г. Ващенка, В. Скуратівського.

Метою статті $\epsilon$ вивчення стану підготовки майбутніх вихователів до застосування народної математики в практиці навчання дітей дошкільного віку в умовах інклюзивної групи.

Виклад основного матеріалу дослідження. Пріоритетним завданням системи вищої освіти $є$ підготовка майбутніх вихователів до реалізації в подальшій професійній діяльності нового змісту освіти, який відкриває доступ до навчання всім дітям дошкільного віку в умовах інклюзивної групи.

Основні концептуальні положення щодо осучаснення та подальшого розвитку вищої педагогічної освіти закладено в Законах України «Про освіту», «Про вищу освіту», у Концепції Нової української школи, Національній стратегії розвитку освіти в Україні на період до 2021 року та «Концепції розвитку освіти України на період 20152025 років». Роботу в інклюзивних групах унормовано Законами України «Про державну соціальну допомогу інвалідам 3 дитинства та дітям-інвалідам», «Про основи соціальної захищеності інвалідів в Україні», «Про реабілітацію інвалідів в Україні», а також Постановою Кабінету міністрів України «Про схвалення Концепції ранньої соціальної реабілітації дітей-інвалідів» та Концепцією стандартів освіти осіб з вадами слуху та низкою інших документів.

Проблема підготовки педагогічних кадрів знаходиться в царині наукових інтересів багатьох учених. Зокрема, вивчаються психологічні основи професійного становлення педагога (О. Леонтьєв, С. Рубінштейн); формування педагогічної майстерності (I. Зязюн, Л. Кондрашова, В. Семиченко); професійна компетентність (Н. Бібік, I. Зимня, О. Овчарук, О. Пометун, Л. Хоружа, А. Хуторський); готовність до педагогічної діяльності (А. Алексюк, В. Бондар, М. Євтух, Н. Кузьміна, В. Сластьонін, С. Сисоєва, О. Ярошенко).

Дослідниця О. Самсонова розглядає вихователя закладу дошкільної освіти, що реалізує інклюзивну практику, як носія чотирьох типів професійних компетенцій, що становлять ядро професійної кваліфікації, а саме:

1) гностична компетенція (полягає у тому, що вихователь обізнаний з нормативноправовою базою щодо інклюзивної освіти, а також психологічними теоріями розвитку дошкільників із різним рівнем психофізичного розвитку та основами корекційної педагогіки й спеціальної психології);

2) діяльнісна компетенція передбачає визначення вихователем:

a) особливостей дошкільників із психофізичними порушеннями та складання адаптованої освітньої програми;

б) педагогічних засобів досягнення освітніх цілей та завдань відповідно до специфіки розвитку вихованців;

в) предметно-розвивального середовища, на базі якого відбуватиметься вирішення освітніх завдань з урахуванням рівня психофізичного розвитку кожного дошкільника;

3) комунікативна компетенція, яка передбачає:

а) здатність працювати в міждисциплінарній команді фахівців для вирішення завдань у галузі психолого-педагогічної діяльності 3 метою формування системи позитивних міжособистісних стосунків, психологічного клімату та організаційної культури у дошкільному навчальному закладі; 
б) уміння організувати міжособистісні контакти, спілкування та спільну діяльність дітей та дорослих;

в) здатність до побудови соціальної взаємодії за принципом толерантності;

г) уміння допомогти дошкільникам у новій ситуації (емоційній, поведінковій, когнітивній) у розв'язанні конфліктів;

д) здатність організувати конструктивну взаємодію 3 батьками на основі партнерських стосунків з метою забезпечення оптимальної підтримки для задоволення потреб вихованців у процесі навчання та розвитку;

4) професійний розвиток (спрямований на здійснення демонстрації власних занять iз критичним обговоренням, проектування та реалізацію науково-методичних проектів тощо) (Самсонова, 2011).

Традиційна система професійної підготовки майбутніх вихователів здійснюється на загальнонауковому, загальнопедагогічному і фаховому рівнях. Цей процес охоплює психолого-педагогічні цикли навчальних дисциплін і всі види навчальнодослідницької діяльності студентів. Система навчання в сучасній вищій школі базується на стандартах, нормативах і фіксованих програмах дій як викладача, так i студентів. При такому способі здобуття освіти майбутні фахівці переважно засвоюють репродуктивну стратегію вирішення життєвих і професійних проблем.

Інклюзивна компетентність майбутніх вихователів - це інтегративне особистісне утворення, яке обумовлює здатність здійснювати професійно-педагогічні функції в процесі інклюзивного навчання, враховуючи різні освітні потреби дітей і забезпечує включення дитини 3 особливими освітніми потребами в середовище загальноосвітнього закладу та створення умов для іiі розвитку і саморозвитку.

Виходячи із зазначеного вище, можна зробити висновок, що стан підготовки майбутніх вихователів у педагогічному вузі до роботи 3 дітьми 3 різними освітніми потребами в умовах інклюзивної групи потребує відповідних змін у змісті психологопедагогічної підготовки студентів як частини обов'язкових знань та засобів діяльності, які необхідно засвоїти. Однак існуюча традиційна форма підготовки майбутніх вихователів не в повному обсязі забезпечує їх успішну підготовку до реалізації інклюзивної освіти, адже викладається лише один предмет «Інклюзивна освіта», у процесі вивчення якого засвоюються лише теоретичні знання, а практика в закладах 3 інклюзивною формою навчання відсутня.

Україна лише виходить на шлях інклюзивої освіти, і ті методики, які розроблені за кордоном, не зовсім відповідають реаліям сьогодення для наших дітей. Це і відмінність менталітету, і багаторічне ігнорування проблеми владою, і незрілість суспільства до повноцінної інтеграції дітей з особливими потребами в соціум.

У Конституції України зазначено, що інклюзивне навчання передбачає створення освітнього середовища, яке б відповідало потребам і можливостям кожної дитини, незалежно від особливостей іiі психофізичного розвитку (Верховна Рада України, 2007). Навчання відбувається за індивідуальним навчальним планом, забезпечується медико-соціальним та психолого-педагогічним супроводом.

Проте на практиці у нас лише останніми роками почали проектувати житло, навчальні заклади, офіси з урахуванням потреб людей з інвалідністю. Здебільшого в будинках-багатоповерхівках й дотепер відсутні пандуси або встановлені із порушеннями, що унеможливлює користування ними. Це саме стосується і закладів освіти - від ЗДО до ЗВО. І навіть, якщо пандус встановлений і дитина зможе самостійно заїхати в будинок - залишається низка проблем у самому приміщенні: вузькі дверні пройоми, високі пороги, відсутність санітарної кімнати для людей 3 інвалідністю тощо.

Окрім наявних технічних проблем, $є$ i концептуальні. Ми не можемо сліпо перейняти закордонні методики навчання дітей в умовах інклюзивних груп. Парадигма сучасної дошкільної освіти націлена на національне виховання. Тому слід зробити 
переорієнтацію дошкільної освіти, де пріоритетом будуть національні педагогічні надбання.

Народна педагогіка - це саме те, що може стати одним із ключових чинників полегшення змісту та методики навчання дітей дошкільного віку в умовах інклюзивної освіти.

Наш науковий інтерес стосується народної математики, тому проблему будемо розглядати з цієї позиції.

У процесі підготовки здобувачів вищої освіти слід звертати увагу на можливості народної математики, адже вона першочергово сприяє активізації математичного словника дітей дошкільного віку.

Педагог О. Шустікова під час занять апробувала елементи народної лічби, довівши, що їх застосування сприяє логіко-математичному розвитку дошкільників.

Український етнограф М. Драгоманов (1876 р.) зібрав і упорядкував цікаві народні задачі. Важливу роль народним задачам, прийомам лічби і вимірювання відводить і К. Щербина. Він вказує, що збирання й уважне вивчення народних математичних знань має величезне значення, адже вони дають дуже цікаві дидактичні, а іноді й методичні вказівки.

Проте найгрунтовніше дослідження 3 історії розвитку народної математики в Україні провела Л. Граціанська. Ознайомлюючи нас зі способами лічби та вимірювання, народними мірами українців на різних етапах історичного розвитку, відкриваючи цікавий світ еволюції поняття числа та його властивостей, а також процес формування просторових уявлень і знань у галузі геометрії, автор дозволяє нам проникнути в глибини народної мудрості. Дослідниця узагальнила матеріал, зібраний у містах і селах України (1925-1968 рр.) за пропозицією К. Щербини.

Л. Плетеницька також цікавилася народною математикою, зокрема ознайомленням дітей із засобами лічби, народними мірами та народним математичним письмом.

Проблему вимірювання за допомогою народних мір та особливості обчислювальної діяльності дітей дошкільного віку досліджувала Н. Баглаєва (Баглаєва, 2001). Для вимірювання українці використовували частини власного тіла, тому назви одиниць мір звучали відповідно: палець, долоня, стопа, лікоть, крок, розмах рук.

Геометричні знання наші предки використовували під час ведення господарства, будівництва та розпису будинків; застосовувалося майстрами столярного та ткацького мистецтва, під час вишивання.

О. Яловська систематизувала загадки математичного змісту за такими темами: кількість і лічба, величина, форма, орієнтування в просторі і часі. Особливу увагу дослідниці привернула народна мудрість щодо формування уявлень про час.

Дослідник В. Скуратівський зібрав різноманітний матеріал про походження назв українських місяців та пов'язані з ними прислів'я і приказки, зразки завбачень погоди, народні свята. Це перше систематизоване дослідження про народний календар українців (Скуратівський, 1993).

Сучасні вчені Л. Білецька, М. Дорошенко, Л. Силюга, Н. Стасів, Н. Сов'як та ін. також розглядають народну математику як основу виховання культури української нації.

Найтоншими засобами впливу на психіку дітей є залучення духовної скарбниці народного фольклору: колядок, приказок, прислів”їв, загадок тощо. Адже цілеспрямоване ознайомлення дітей дошкільного віку з малими жанрами фольклору збагачує пізнавальну та розумову діяльність, формує здатність відгукуватися на яскраву образну мову. Завдяки прислів'ям дошкільники дізнаються про образність, конкретність, влучність (Богуш, 2002).

Елементи народознавства використовуються як у повсякденному житті, так і на інших заняттях: 3 зображувальної діяльності (малювання, ліплення, аплікація); 3 рідної природи, художньої літератури, розвитку мовлення, грамоти та інших. 
Сучасні дошкільники не досить добре розуміють поняття народної математики, адже вона на сьогодні не $є$ в широкому вжитку. Водночас, діти постійно чують невідомі їм слова, зокрема у казках. Тому методика ознайомлення дошкільнят 3 термінами народної математики передбачає пояснення понять; відображення їх у різних жанрах усної народної творчості; ознайомлення з ними у бесіді, розповіді, дидактичній грі.

В умовах інклюзивної групи сучасного закладу дошкільної освіти необхідно постійно використовувати елементи народної математики, розповідати історію виникнення математичних понять та термінів. Це не лише підвищить інтерес до вивчення математичного матеріалу, а й сприятиме формуванню любові до власного народу, виховання патріотичних почуттів. Саме це слід враховувати у процесі підготовки майбутніх вихователів до професійної діяльності.

Висновки та перспективи подальших розвідок. Проблема підготовки майбутніх вихователів до застосування народної математики в практиці навчання дітей дошкільного віку в умовах інклюзивної групи базується на науково-теоретичних i експериментальних розробках психологів та педагогів, в яких доведено можливість i механізми формування в дошкільників математичних уявлень, доступність для їхнього розуміння термінів народної математики, послідовність етапів опрацювання цих понять.

Перспективу подальших досліджень вбачаємо у запровадженні експериментальної програми з народної математики для підготовки дітей дошкільного віку в умовах інклюзивної групи.

\section{СПИСОК ВИКОРИСТАНИХ ДЖЕРЕЛ}

Самсонова, Е. (2011). Развитие профессиональной компетентности педагога дошкольного образовательного учреждения, реализующего инклюзивную практику. В: Инклюзивное образование: методология, практика, технологии. Москва: МГППУ. С. 171-172.

Верховна Рада України, (2007). Конституція України. Харків: ПП «Інгвін». 80 с.

Баглаєва, Н. (2001) Вимірювання - цікаво і корисно, Дошкільне виховання. № 5. С. 8-9.

Скуратівський, В. (1993). Місяцелік: Український народний календар. Київ: Мистецтво. 208 с.

Богуш, А. (2002). Украӥнське народознавство в дошкільному закладі. 2-ге вид., переробл. і доповн. Київ: Вища школа. С. 321-335.

\section{REFERENCES}

Samsonova, Ye. (2011). Razvitiye professionalnoy kompetentnosti pedagoga doshkolnogo obrazovatelnogo uchrezhdeniya, realizuyushchego inklyuzivnuyu praktiku [Development of Professional Competence of a Teacher of a Preschool Educational Institution That Implements Inclusive Practice]. V: Inklyuzivnoye obrazovaniye: metodologiya, praktika, tekhnologii. Moskva: MGPPU. S. 171-172. (in Russian)

Verkhovna Rada Ukrayiny, (2007). Konstytutsiia Ukrainy [The Constitution of Ukraine]. Kharkiv: PP “Inhvin”. 80 s. (in Ukrainian)

Bahlaieva, N. (2001). Vymiriuvannia - tsikavo i korysno [Measurement. It Is Interesting and Useful]. Doshkilne vykhovannia. No 5. S. 8-9. (in Ukrainian)

Skurativskyi, V. (1993). Misyatselik: Ukraiinskyi narodnyi calendar [Moonlight: Ukrainian Folk Calendar]. Kyiv: Mystetstvo, 208 s. (in Ukrainian)

Bohush, A. (2002). Ukrainske narodoznavstvo $v$ doshkilnomu zakladi [Ukrainian Ethnography in Preschool]. 2-he vyd., pererobl. i dopovn. Kyiv: Vyshcha shkola. S. 321335. (in Ukrainiian) 


\title{
PREPARATION OF FUTURE PRESCHOOL TEACHERS FOR THE USE OF FOLK MATHEMATICS IN PRACTICE OF TEACHING PRESCHOOL CHILDREN IN THE CONTEXT OF INCLUSIVE GROUP
}

\author{
Tatiana Pavliuk \\ Candidate of Pedagogical Sciences, Associate Professor, \\ Associate Professor at the Department of Pedagogy \\ and Psychology (Preschool and Correctional) \\ named after Professor T.Ponimanska, \\ Rivne State University for the Humanities, \\ Rivne, Ukraine \\ ORCID : 0000-0001-7237-0869 \\ e-mail:nadahovskat@ukr.net
}

\begin{abstract}
The article deals with the preparation of future teachers for the use of elements of folk mathematics in modern preschool education institutions. The views of scientists on the identified problem taking into account the requirements of today are highlighted in particular educating children with disabilities together with healthy peers in an inclusive setting. In this article, a pre-school teacher who implements inclusive practices is presented as a carrier of four types of professional competencies that form the core of professional qualification, namely: gnostic competence, activity competence, communicative competence and professional development.

It is proved that the traditional system of professional training of future teachers of preschool education institution is carried out at the general scientific, general pedagogical and professional levels. It is determined that the state of preparation of future teachers in pedagogical university to work with children with different educational needs in the conditions of an inclusive group requires corresponding changes in the content of psychological and pedagogical prteparation of students as part of the compulsory knowledge and means of activity, which must be mastered.

The factors affecting the lack of intensive implementation of inclusive education in Ukraine. and creating a space friendly to children with special needs are considered, in particular, with disorders of the musculoskeletal system. Attention is focused on improving the effectiveness of training higher education applicants thanks to the revival of methodological methods of educating of the younger generation by means of folk mathematics. The material on folk mathematics is organically combined with modern methods of forming elementary mathematical ideas in preschool children, complements and rationalizes the educational process, and also promotes cognitive interest in learning. The material is structured in accordance with the modern content of the formation of elementary mathematical representations in preschool children: the formation of ideas about the plural, the teaching of numbers, familiarity with the number and number, the study of measurement and the solving of arithmetic tasks, familiarity with the form and geometric figure.
\end{abstract}

Keywords: preschool child, child with special educational needs, inclusion, inclusive group, folk mathematics, institution of preschool education, future teacher.

Стаття надійшла до редакиії 14.10.2019 р. 